\title{
Descriptions of the egg case and larva of Anacaena and a review of the knowledge and relationships between larvae of Anacaenini (Coleoptera: Hydrophilidae: Hydrophilinae)
}

\author{
Miguel ARCHANGELSKY ${ }^{1}$ and Martin FIKÁČEK ${ }^{2}$ \\ ${ }^{1}$ CONICET-LEA, Laboratorio de Ecología Acuática, Universidad Nacional de La Patagonia, San Juan Bosco, Sarmiento 849, \\ 9200, Esquel, Chubut, Argentina; e-mail: hydrophilidae@hotmail.com \\ ${ }^{2}$ Department of Zoology, Faculty of Natural Sciences, Charles University, Viničná 7, CZ-128 44 Praha 2, Czech Republic; \\ e-mail: fikacek1@natur.cuni.cz
}

Key words. Anacaena, Paracymus, Anacaenini, Hydrophilidae, Coleoptera, larva, egg case, Argentina, Neotropics

\begin{abstract}
The third instar larva of Anacaena cordobana Knisch, and the egg case of Anacaena lutescens (Stephens) are described and illustrated. The taxonomic status of the immature stages of Anacaenini is clarified by comparing their morphology with that described in the literature. Larval descriptions of Anacaena and Paracymus published by Richmond (1920) are interchanged, as are the identifications of all subsequent authors based on Richmond's work. All Anacaenini genera for which larvae are known are diagnosed. A comparative morphological study of Anacaena larvae shows many similarities between Crenitis and Anacaena larvae, suggesting a close relationship between these two genera.
\end{abstract}

\section{INTRODUCTION}

The tribe Anacaenini includes more than 200 species, distributed in 10 genera. The members of this tribe are small beetles, ranging between $1.0-4.5 \mathrm{~mm}$ in length. Over the last 10-15 years several new genera were described (Hansen, 1999a; Gentili, 2002b) and others revised for some geographical regions (Berge Henegouwen, 1986; Gentili, 1992, 1993, 1996, 2000, 2002a, b; Hebauer, 1994, 1999, 2001a, b, 2002; Hansen, 1999b; Bameul, 2001; Ji \& Komarek, 2003) (Table 1). Despite this a worldwide revision of this tribe is needed. The reasons for this, cited by several authors (Hansen, 1991, 1999a; Hebauer, 1994; Archangelsky, 1999), are the highly variable morphology and poor definition of the boundaries among some of the genera (especially the group formed by Paracymus Thomson, 1867, Anacaena Thomson, 1859, Paranacaena Blackburn, 1888 and Crenitis Bedel, 1881).

A few years ago one of the authors collected an interesting larva associated with adults of Anacaena cordobana Knisch, 1924 in central La Rioja province (Argentina). Several collecting trips in the same locality (and others nearby where the same species is common), looking for additional larvae, were unsuccessful. In more than one occasion adults were kept alive in the laboratory in an attempt to get them to breed, but again without positive results. The larva has characters of larvae of the genera Anacaena and Crenitis. For this reason we consider it is appropriate to describe this unique larva based on one specimen. On the basis of the morphology of this specimen, we discuss the associations of previously described larvae of the genera Anacaena and Paracymus.

\section{MATERIAL AND METHODS}

The larva was collected at Chuquis in March 1999, fixed in the field in ethyl alcohol $(80 \%)$, cleared in lactic acid, dissected and mounted on slides for description; the medium used was Hoyer's. Descriptions and illustrations were made using a camera lucida attached to a Leica DMLB compound microscope.

To rule out the possibility of a wrong association, all the Anacaenini specimens collected in that area between 1998 and 2001 were revised. The only Anacaenini genus collected there was Anacaena. A bibliographic revision confirmed that there are no Crenitis species in Argentina (Fernández \& Bachmann, 1998; Hansen, 1999b; Oliva et al., 2002). The only two Crenitis species in South America (one from Paraguay and one from Bolivia) occur far from La Rioja province. Thus it is improbable that the larva we describe could belong to the genus Crenitis.

An egg case was laid by adults kept in a plastic rearing box containing about $2 \mathrm{~cm}$ of water and pieces of mosses. The egg case was drawn using a MBS-10 microscope with an ocular grid. The egg case was then placed in a Petri dish with wet filter paper, but did not hatch. Because of mould it was not preserved and the eggs were not counted.

The adults were identified using the keys by Orchymont (1942), Hansen (1991), Gentili (1996) and Oliva et al. (2002). Albrecht Komarek confirmed the identification.

\section{RESULTS}

\section{Anacaena cordobana Knisch, 1924}

Material studied. Argentina, La Rioja province, Departamento Castro Barros, $\mathrm{A}^{\circ}$ Chuquis, Chuquis, 2.iv.1999, $29^{\circ} 09^{\prime} 45^{\prime}$ 'S, 6704'48”'W, 1300 m, M. Archangelsky lgt. (1 larva).

\section{Description of third instar larva}

Length $2.7 \mathrm{~mm}$, almost parallel sided, wider between second and fourth abdominal segments (Fig. 1). Colour light brown, with sclerotized parts darker; non-sclerotized 
TABle 1. Number of species described in each genus in different periods from 1792-2003, and the total number of species in each genus of Anacaenini. Based on data from Hansen (1999b) and recent revisions cited in the introduction.

\begin{tabular}{|c|c|c|c|c|c|c|c|}
\hline \multirow{2}{*}{ Genus } & \multicolumn{6}{|c|}{ Number of species described } & \multirow{2}{*}{ Total spp. } \\
\hline & $1792-1899$ & $1900-1949$ & $1950-1979$ & $1980-1989$ & $1990-1999$ & $1999 *-2003$ & \\
\hline Enigmata & - & - & - & - & 1 & - & 1 \\
\hline Notohydrus & 2 & - & - & - & 3 & - & 5 \\
\hline Paracymus & 12 & 17 & 42 & 3 & 1 & 6 & 81 \\
\hline Crenitis & 7 & 8 & 8 & 2 & 14 & 2 & 40 \\
\hline Phelea & - & - & - & - & 1 & - & 1 \\
\hline Grodum & - & - & - & - & 2 & - & 2 \\
\hline Anacaena & 15 & 26 & 7 & 2 & 3 & 6 & 59 \\
\hline Paranacaena & 4 & 2 & - & - & 15 & 15 & 36 \\
\hline Notionotus & - & - & 2 & 3 & - & 8 & 13 \\
\hline Hebauerina & - & - & - & - & - & 1 & 1 \\
\hline Spp. described & 40 & 53 & 59 & 10 & 40 & 38 & 239 \\
\hline
\end{tabular}

1999* descriptions not included in Hansen (1999b).

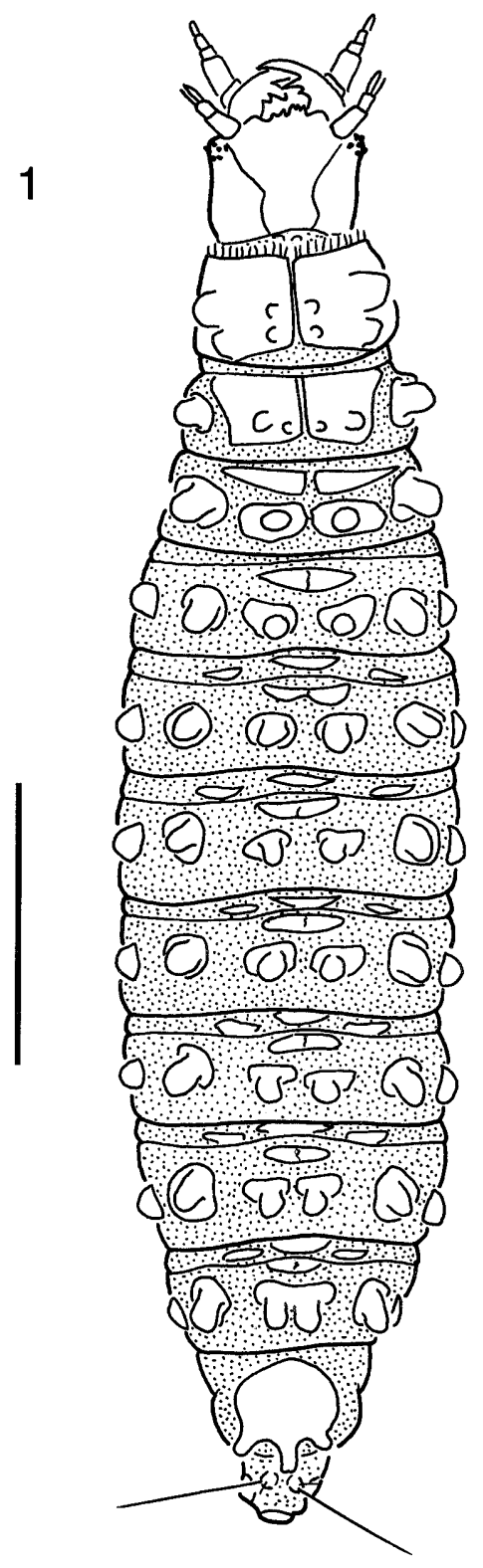

Fig. 1. Anacaena cordobana. Habitus. Scale bar $=0.5 \mathrm{~mm}$. integument covered by small cuticular asperities, denser on dorsal side.

Head capsule subquadrate (Fig. 2); occipital foramen wide, cervical sclerites absent. Frontoantennal lines lyriform, reaching base of head capsule without fusing, coronal line absent. Vertex of head with vestiture of small and flat, tooth-like cuticular projections pointing anteriad. Six stemmata closely aggregated on each anterolateral corner of head capsule, close to antennal socket.

Clypeolabrum asymmetrical (Fig. 3). Nasale with 5 teeth, three on right more closely aggregated and projecting further than two on left; six short setae intercalated among teeth. Lateral lobes of epistome rounded, symmetrical, not projecting further than nasale, each with four slender setae, outer one short and stout, inner three long and slender. Inner edge of antennal socket with one long, stout and distally branched seta.

Mandibles symmetrical (Fig. 4), with three inner teeth, distal two large, inner one small. Apex of mandible feebly serrated on inner margin. Outer margin of mandible with five short setae.

Antennae trimerous (Fig. 5), short, stout, covered with narrow and sharp cuticular spines forming a sparse pubescence, denser on ventral side. Scapus the longest, bearing three campaniform sensilla. Pedicel the shortest, with three short distal setae, two on outer margin, one on inner margin; distal sensorial appendage present on outer apical margin, narrow, as long as flagellum. Flagellum slightly shorter than scapus, with four apical setae or sensoria, and one basal seta on inner margin.

Maxillae, counting cardo, hexamerous (Fig. 6), slightly longer than antennae. Cardo small, subdivided, irregularly shaped. Stipes subquadrate, with pubescence on inner margin formed by fine cuticular spines; inner margin with row of five stout setae; outer margin with three setae, one long and two short. Palp tetramerous, second and third palpomeres the shortest; basal palpomere the widest, incompletely sclerotized on dorsal side, bearing one seta on inner margin and three on ventral side, inner process membranous, with three distal setae; second palpomere 


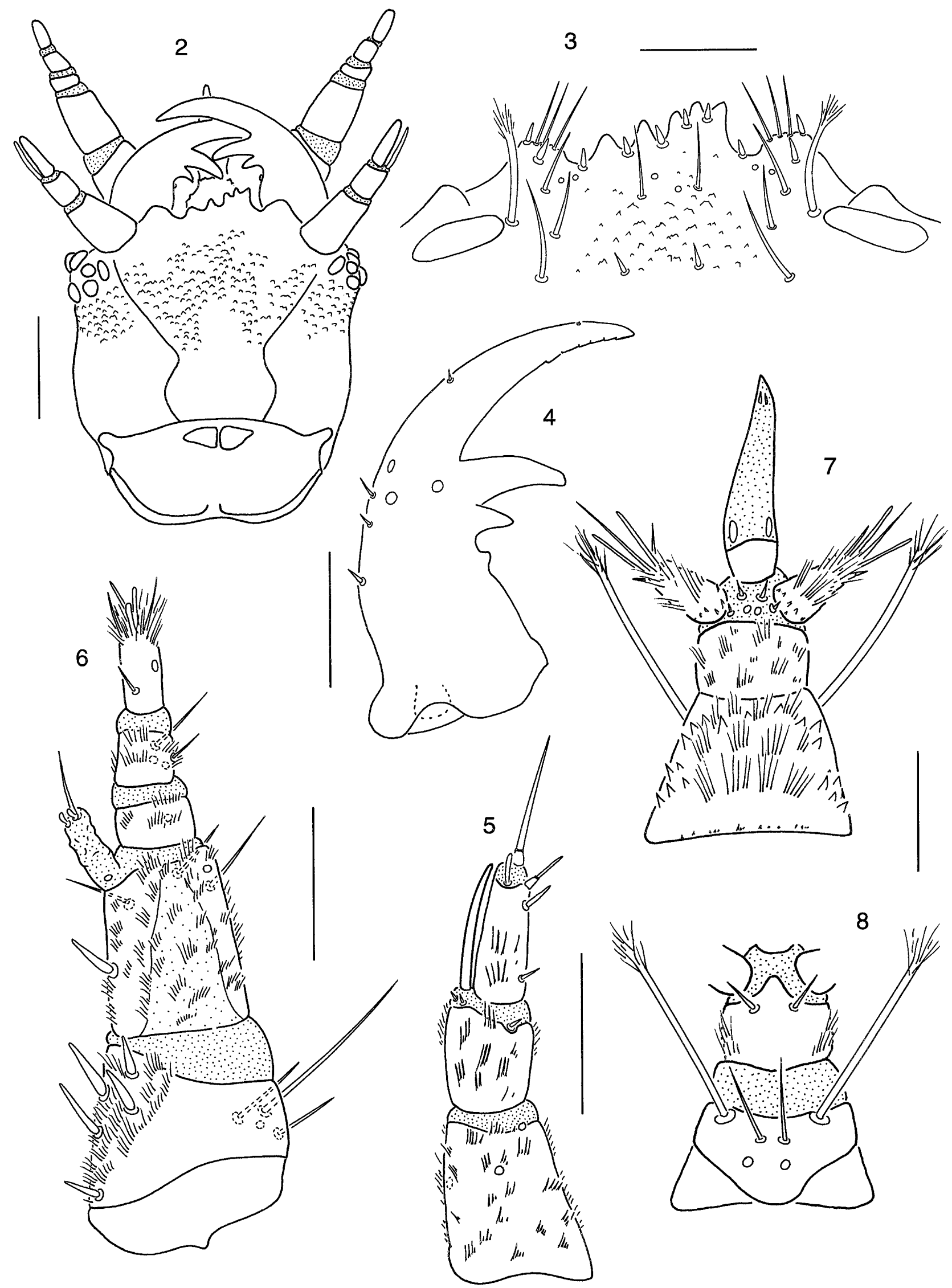

Figs 2-8. Morphology of Anacaena cordobana. 2 - head, dorsal view; 3 - clypeolabrum, dorsal view; 4 - left mandible, dorsal view; 5 - left antenna, dorsal view; 6 - right maxilla (cardo not included), dorsal view; 7 - labium, dorsal view; 8 - labium, ventral view. Scale bars: $2=0.1 \mathrm{~mm} ; 3-8=0.05 \mathrm{~mm}$. 

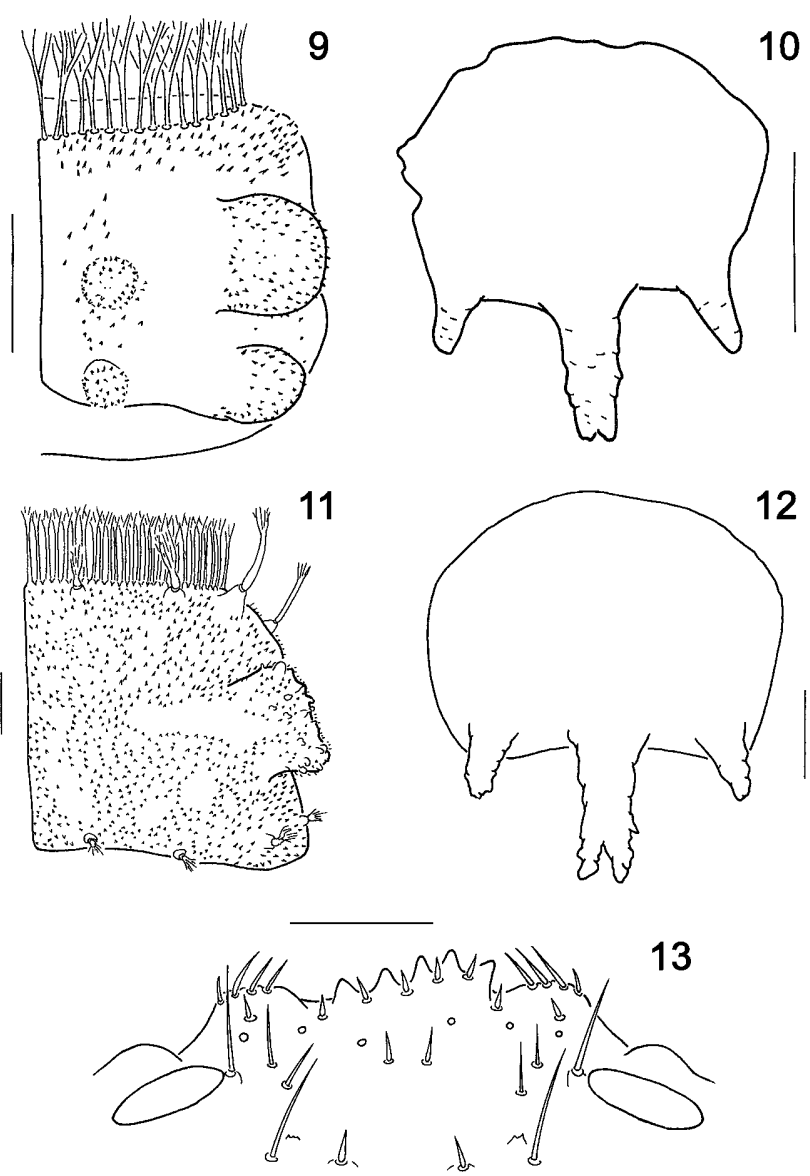

Figs 9-13. Morphology of Anacaena cordobana (9-10) and Crenitis morata (11-13). 9 - pronotal shield, right side; 10 tergal plate of abdominal segment VIII; 11 - pronotal shield, right side; 12 - tergal plate of abdominal segment VIII; 13 clypeolabrum, dorsal view. Scale bars $=0.1 \mathrm{~mm}$.

short, lacking setae; third palpomere with two subapical setae on ventral side; last palpomere bearing one basal seta, projecting mediad, and five short distal setae. Pubescence of first three palpomeres short and evenly distributed, that of fourth palpomere long, restricted to apex.

Labium well developed (Figs 7-8), with dense pubescence formed by long and fine cuticular projections on dorsal side. Submentum large, subpentagonal, wider than mentum. Mentum trapezoidal in dorsal view, anterior and lateral margins with strong cuticular spines; ventral anterior margin with two pairs of setae, outer ones long, distally branched. Prementum rectangular, wider than long, with two pairs of short setae close to base of palpi on dorsal side, two short setae on ventral side. Ligula longer than palpi, mostly membranous; labial palpi short, apparently monomerous, bearing five or six apical setae and sensoria.

Prothorax wider than head capsule (Fig. 1). Proscutum formed by one large plate divided by fine sagittal line, each side with two lateral lobed projections (Fig. 9), and two smaller lobes closer to midline; anterior margin and pronotal lobes covered by small, sharp spicules; anterior margin of proscutum with fringe of long, deeply branched

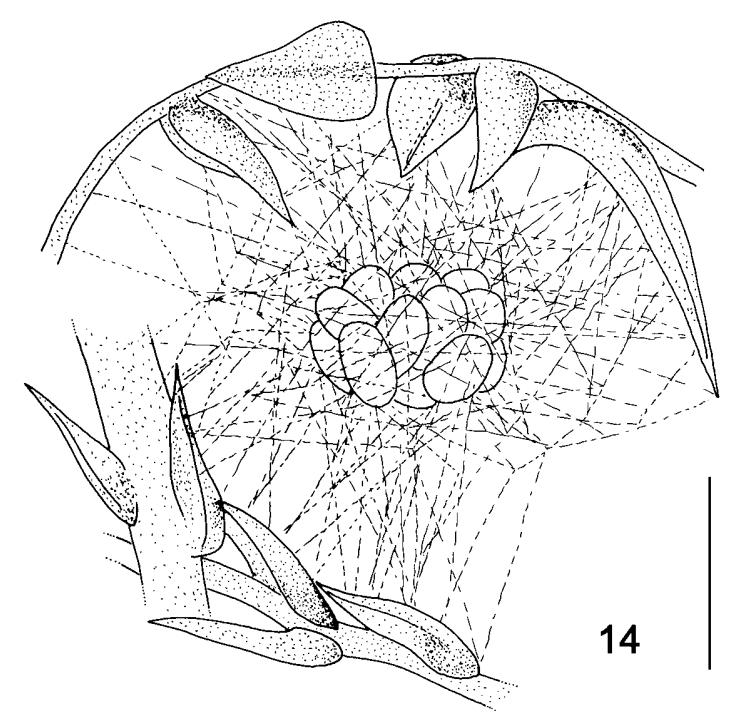

Fig. 14. Anacaena lutescens, egg case. Scale bar $=1 \mathrm{~mm}$.

setae. Presternum subpentagonal, with short incomplete sagittal line on base. Mesonotum with one dorsal sclerite and one lateral sclerite on each side; inner sclerite large, subdivided by sagittal line, with two lobes, outer lobe larger, lateral sclerites with a large lobe; metanotum with six sclerites, anterior two narrow, subtriangular, posterior two pairs larger, each with a large lobe. Legs short, not visible in dorsal view, five-segmented, all three pairs similar in shape, covered by dense pubescence.

Abdomen ten-segmented, tapering towards posterior end, segments VIII and IX forming spiracular atrium (Fig. 1), segment X reduced. Segments I to VII similar in size and shape, each with several sclerites and subdivided by a transverse fold. Segment I with six plates, anterior ones small, touching along midline, posterior ones with sclerotized lobes, an additional lobed plate on each pleural region; segments II to VI similar to segment I except for three poorly sclerotized narrow plates on anterior fold of segment; segment VII with two inner lobed plates fused. Segment VIII (Figs 1, 10) with large dorsal suboval plate, its posterior edge trifurcated. Segment IX trilobed, partially covered by eighth, with a pair of short, one-segmented urogomphi.

Nine pairs of spiracles, one on mesothorax and eight abdominal. Thoracic and first seven abdominal pairs of spiracles non-functional. Last abdominal pair enclosed within spiracular atrium.

\section{Anacaena lutescens (Stephens, 1829)}

Reared adults: Czech Republic, Praha - Kunratice, Šeberák pond, 5000’36”N, 14³0’00”E; 200 m; 11.iii.2002, M. Fikáček lgt. (20 adults).

\section{Description of the eggs and egg case}

Eggs white in colour, oval in shape, measuring $0.28 \times$ $0.53 \mathrm{~mm}$, aggregated in a compact group, surrounded by a very loosely swollen net of fibers, which are attached to a plant (Fig. 14). Egg case built in moss just above the water surface. 
TABLE 2. State of knowledge and source of information on the immature stages of the tribe Anacaenini.

\begin{tabular}{|c|c|c|c|c|}
\hline (Probable) correct identification & Original identification & Original association & $\begin{array}{l}\text { Described } \\
\text { stages }\end{array}$ & Reference \\
\hline \multirow[t]{2}{*}{ Crenitis punctatostriata (Letzner, 1840) } & C. punctatostriata & ESI & $\mathrm{L} ?$ & van Emden (1932) \\
\hline & & $\mathrm{R}$ & $\mathrm{P}$ & Matthey (1977) \\
\hline Crenitis morata (Horn, 1810) & C. morata & ESI & L3 & Archangelsky (1997) \\
\hline Notionotus liparus Spangler, 1972 & N. liparus & $\mathrm{R}$ & $\mathrm{L} 1$ & Archangelsky (1997) \\
\hline Anacaena lutescens (Stephens, 1829) & $\begin{array}{l}\text { "A. limbata var. nitida } \\
\text { (Heer, 1841)" }\end{array}$ & $\mathrm{R}(?)$ & $\mathrm{L}$ ? & Orchymont (1912) \\
\hline Anacaena marchantiae (Wollaston, 1857) & A. marchantiae & ESI & $\mathrm{L}$ ? & Orchymont (1940) \\
\hline Anacaena cordobana Knisch, 1924 & A. cordobana & ESI & L3 & here described \\
\hline Anacaena sp. & $\begin{array}{l}\text { "Paracymus subcupreus } \\
\text { Say" }\end{array}$ & $\mathrm{R}$ & E, L1, L3, P & Richmond (1920) \\
\hline Anacaena sp. & "Paracymus aeneus Germ." & $\begin{array}{l}\text { DES (Richmond } \\
\text { 1920) }\end{array}$ & L? & $\begin{array}{l}\text { Bøving \& Henriksen } \\
\text { (1938) }\end{array}$ \\
\hline Paracymus pygmaeus (MacLeay, 1871) & $\begin{array}{l}\text { Anacaena tepida } \\
\text { Winterbourn, } 1970\end{array}$ & ESI & $\mathrm{L} ?$ & Winterbourn (1971) \\
\hline Paracymus subcupreus (Say, 1825) & P. subcupreus & $\mathrm{R}$ & E, L3, P & Archangelsky (1997) \\
\hline Paracymus rufocinctus Bruch, 1915 & P. rufocinctus & $\mathrm{R}$ & E, L1, L3, P & Archangelsky (1999) \\
\hline
\end{tabular}

Abbreviations: ESI = ex societas imaginalis (i.e. adults collected together with immature stages); $\mathrm{R}=$ reared from from eggs laid by adults in the laboratory; DES = determined by reference to literature, which is given in parenthesis; $\mathrm{E}=$ egg case/eggs; L? = larval instar unknown; L1, L3 = larva of first or third instar; $\mathrm{P}=$ pupa.

\section{DISCUSSION}

\section{Taxonomic status of immature stages of Anacaenini}

The status of the knowledge on Anacaenini larvae was summarized by Archangelsky (1997, 1999). In addition, there are other overlooked and recent references (Orchymont, 1940; Hansen, 2000; Gentili, 2000). All this information combined with the present description have established a clearer framework of larval knowledge within the tribe. The descriptions of the immature stages of Crenitis and Notionotus are most probably based on correctly associated material, but not those of Anacaena and Paracymus. These problematic descriptions are discussed below and the descriptions are summarized in Table 2 .

Immature stages of four species of the genus Anacaena are described: Anacaena infuscata (Motschulsky, 1859), A. limbata var. nitida (Heer, 1841), A. marchantiae (Wollaston, 1857) and A. tepida Winterbourn, 1970. (Richmond 1920; Orchymont, 1913, 1940; Winterbourn, 1971).

Anacaena tepida was recently synonymized with Paracymus pygmaeus (MacLeay, 1871) by Hansen (2000) on the basis of adult morphology. The larva, described by Winterbourn (1971), bears some characters that differ from those found in Anacaena cordobana: nasale with four teeth, ligula shorter than labial palpi, abdominal segments without large projections, abdominal tergum VIII slightly convex posteriorly. In all these characters it is similar to larvae of Paracymus subcupreus and P. rufocinctus (Archangelsky, 1997, 1999). Thus, the larva described by Winterbourn (1971) belongs to Paracymus not Anacaena.

Orchymont (1940) described the larva of Anacaena marchantiae from Madeira. Although this larva was collected in the field, both its generic and specific associa- tions seem to be correct, because Anacaena is the only genus of Anacaenini occurring on Madeira and other Atlantic islands and A. marchantiae is the only species commonly occurring at low altitudes in Madeira. A second species, A. conglobata (Wollaston, 1854), is very rare and occurs only at high altitudes according to Orchymont (1940). Even though Orchymont's description and figure are not very detailed, it is possible to compare the larval morphology of $A$. marchantiae with that of $A$. cordobana. This comparison reveals some shared characters: nasale with five teeth, proscutum with rounded lateral lobes, posterior margin of abdominal tergum VIII strongly trifid; there are also some differences: nasale symmetrical, ligula shorter than labial palpi, abdominal segments strongly lobed laterally. On the basis of these facts, the larva described by Orchymont (1940) seems to belong to Anacaena.

The larva of "Anacaena limbata var. nitida" (= Anacaena lutescens (Stephens, 1829) according to Hansen, 1999b) was described by Orchymont (1913), but this description was rejected by Richmond (1920) and Bøving \& Henriksen (1938). Both American and Danish authors think this larva belongs to Paracymus. However, Orchymont (1940) gives additional support for his original identification of "Anacaena limbata var. nitida": (1) larvae were reared in captivity from determined adults (this fact is not mentioned in Orchymont, 1913); (2) in Belgium, Paracymus is very rare and therefore it would be unlikely to find larvae of this genus; (3) larvae of " $A$. limbata var. nitida" and $A$. marchantiae are rather similar in their morphology. The larva shares some characters with $A$. marchantiae and/or A. cordobana: symmetrical nasale bearing 5 teeth, ligula shorter than labial palpi (in $A$. cordobana the ligula is longer), proscutum with distinct lateral lobes (but these are small), posterior margin 
TABLE 3. Generic similarities and differences of Anacaenini larvae.

\begin{tabular}{|c|c|c|c|c|}
\hline Structure & Anacaena (Figs 1-10) & Crenitis (Figs 11-13) & Paracymus & Notionotus* \\
\hline Nasale & With 5 teeth & With 5 teeth & With 3-4 teeth & $\begin{array}{l}\text { With 7-8 small irregular } \\
\text { teeth }\end{array}$ \\
\hline Epistomal lobes & $\begin{array}{l}\text { Symmetrical, each with } 4 \\
\text { setae }\end{array}$ & $\begin{array}{l}\text { Symmetrical, each with } 4 \\
\text { setae }\end{array}$ & $\begin{array}{l}\text { Symmetrical, each with 1-2 } \\
\text { setae }\end{array}$ & $\begin{array}{l}\text { Asymmetrical, left with } 2 \\
\text { setae, right bare }\end{array}$ \\
\hline $\begin{array}{l}\text { Inner edge of } \\
\text { antennal socket }\end{array}$ & $\begin{array}{l}\text { With stout, long, branched } \\
\text { seta }\end{array}$ & $\begin{array}{l}\text { With stout, long, simple } \\
\text { seta }\end{array}$ & Without seta & Without seta \\
\hline Antenna & $\begin{array}{l}\text { Sensory appendage thin, as } \\
\text { long as antennomere III }\end{array}$ & $\begin{array}{l}\text { Sensory appendage thin, as } \\
\text { long as antennomere III }\end{array}$ & $\begin{array}{l}\text { Sensory appendage shorter } \\
\text { than antennomere III }\end{array}$ & $\begin{array}{l}\text { Sensory appendage shorter } \\
\text { than antennomere III }\end{array}$ \\
\hline Ligula & $\begin{array}{l}\text { Longer or shorter than } \\
\text { labial palp }\end{array}$ & Longer than labial palp & $\begin{array}{l}\text { Longer or shorter than } \\
\text { labial palp }\end{array}$ & Shorter than labial palp \\
\hline Proscutum & With rounded lateral lobes & With flat lateral lobes & Without lobes & Without lobes \\
\hline $\begin{array}{l}\text { Abdominal } \\
\text { segments I-VII }\end{array}$ & $\begin{array}{l}\text { Slightly to strongly lobed, } \\
\text { but without projections }\end{array}$ & $\begin{array}{l}\text { With long, lateral } \\
\text { fingerlike projections }\end{array}$ & $\begin{array}{l}\text { Slightly to strongly lobed, } \\
\text { but without projections }\end{array}$ & Without projections \\
\hline $\begin{array}{l}\text { Abdominal } \\
\text { tergite VIII }\end{array}$ & $\begin{array}{l}\text { Posterior margin slightly to } \\
\text { strongly trifid }\end{array}$ & $\begin{array}{l}\text { Posterior margin strongly } \\
\text { trifid }\end{array}$ & $\begin{array}{l}\text { Posterior margin straight to } \\
\text { slightly convex }\end{array}$ & $\begin{array}{l}\text { Posterior margin slightly } \\
\text { convex }\end{array}$ \\
\hline
\end{tabular}

* Only first instar larvae of Notionotus are known.

of abdominal tergum VIII slightly trilobed. Different characters, e.g., are mandibles with two inner teeth. For these reasons, the larva described by Orchymont (1913) also seems to belong to Anacaena.

Richmond (1920) described the larva of "Anacaena infuscata". According to the synonymy of Anacaena species, this larva is probably "Anacaena limbata var. nitida" described by Orchymont (1913). Orchymont's description refers to $A$. lutescens according to the synonymy given by Hansen (1999b) and not to A. limbata of previous authors. "Anacaena infuscata" is regarded as a (likely) synonym of Anacaena lutescens by Hansen (1999b) (marked by question mark). Although both descriptions probably refer to the same species, they differ in some basic diagnostic characters (characters in front of parentheses are Richmond's (1920), those in parentheses are Orchymont's (1913): nasale with four teeth (five teeth), mandibles with three teeth (two teeth) and proscutum without lateral lobes (with small lateral lobes). The egg case described by Richmond (1920) also differs from that of Anacaena lutescens (see the above description). All these facts indicate that both descriptions cannot refer to the same species and/or genus. Because Orchymont's larva was correctly identified, Richmond's must have been misidentified and his larva probably does not belong to Anacaena. In addition, the larva described by Richmond (1920) is rather similar to that of Paracymus subcupreus described by Archangelsky (1997), and is therefore likely to belong to Paracymus (see under Paracymus for details).

Shaarawi \& Angus (1991) mention that the egg cases of Anacaena lutescens, A. limbata and A. bipustulata (Marsham, 1802) have a similar form to that described by Richmond (1920) for Paracymus subcupreus. Shaarawi (1989) described the egg case of an unidentified Paracymus species from Corfu (= Kerkira) as resembling that of Helophorus minutus Fabricius, 1775, and thus differing from the egg case described for Paracymus subcu- preus by Richmond (1920). Both these facts indicate that Richmond (1920) mixed up his larval material.

In the genus Paracymus larvae of four species are described: Paracymus pygmaeus (MacLeay, 1871), Paracymus subcupreus (Say, 1825), Paracymus rufocinctus Bruch, 1915 and Paracymus aeneus (Germar, 1824). (Winterbourn, 1971; Richmond, 1920; Archangelsky, 1997, 1999; Bøving \& Henriksen 1938).

The larva of Paracymus pygmaeus was described as "Anacaena tepida" by Winterbourn (1971), as already discussed above.

Larvae of $P$. subcupreus and $P$. rufocinctus were described recently by Archangelsky (1997, 1999). Although both larvae differ in some characters (e.g. shape of labroclypeus), the descriptions are based on material reared from adults and their association is thus surely correct. For a comparison of larval morphology of both species see Archangelsky (1999).

Richmond (1920) also describes the larva of "Paracymus subcupreus", however the morphology of this larva is very different from that described by Archangelsky (1997). The main differences are: nasale with five teeth, mandibles with 2 inner teeth, ligula subdivided and as long as labial palpi, proscutum with small lateral lobes, abdominal terga with numerous projections. In all these characters the morphology of this larva is similar to that of Anacaena cordobana described above. Also, the morphology of the "egg case" described by Richmond (1920) is similar to that described here for Anacaena lutescens. Moreover, Richmond (1920) mentions under Anacaena that "close examination is necessary to be absolutely positive that it is not the closely related Paracymus subcupreus" and that both species are "very often taken together". For all these reasons, this larva seems to belong to Anacaena. On the other hand, Archangelsky's description of Paracymus subcupreus is very similar to Richmond's description of "Anacaena infuscata" in all diagnostic characters. Taking all these facts into account, 
it seems probable that Richmond (1920) interchanged the larvae of Paracymus and Anacaena.

Bøving \& Henriksen (1938) describe the larva of Paracymus aeneus, but this description is based on material collected in the field. The generic association of this species was made on the basis of Richmond's description of "Paracymus subcupreus", which was misidentified and refers to Anacaena. According to the description and figures of the larva of "Paracymus aeneus", this larva shares some characters with larvae of Anacaena: nasale slightly asymmetrical with five teeth, sensory appendage as long as flagellum, mandibles symmetrical with two inner teeth, ligula subdivided and as long as labial palpi, proscutum with rounded lateral lobes, posterior margin of abdominal tergite VIII slightly trilobed. Based on these characters, and the proposed misidentification made by Richmond (1920), the larva described by Bøving \& Henriksen (1938) probably belongs to Anacaena and not to Paracymus.

Summarizing the above information on the problematic descriptions of immature stages of Anacaena and Paracymus:

Richmond (1920) interchanged the descriptions of Anacaena and Paracymus, describing immature stages of Anacaena as "Paracymus subcupreus" and immature stages of Paracymus as "Anacaena infuscata". Later authors subsequently adopted this concept, therefore in all subsequent papers, except those of Orchymont (1913, 1940), Archangelsky (1997 - only in case of Paracymus subcupreus) and Archangelsky (1999), the genera Paracymus and Anacaena are interchanged.

The description of "Anacaena limbata var. nitida" (Orchymont, 1913) correctly refers to the genus Anacaena.

The description of the larva of "Anacaena tepida" (Winterbourn, 1971) is in fact that of Paracymus pygmaeus.

\section{Comparative notes on larvae of other Anacaenini genera}

The larvae of Anacaena have diagnostic characters that define the tribe Anacaenini, according to Archangelsky (2004): maxilla with appendage of first palpomere unsclerotized, legs not visible in dorsal view, a relatively short stipes, and a long first palpomere.

Based on what is known of other Anacaenini larvae, we present a table summarizing the principal similarities and differences among larvae of the genera Anacaena, Crenitis, Paracymus, and Notionotus (Table 3). This table is based on material studied for this paper (Anacaena cordobana, Crenitis morata (Horn, 1890), Paracymus rufocinctus, P. subcupreus, and Notionotus liparus Spangler, 1972), and descriptions in the literature.

Even though no phylogenetic analysis was performed, some conclusions based on larval morphology can be drawn. Anacaena and Crenitis show many similarities: (1) shape of the nasale and epistomal lobes (Figs 3, 13); (2) presence of seta on inner margin of the antennal socket (Figs 3, 13); (3) the closely aggregated and protuberant stemmata; (4) the long and narrow antennal sen- sory appendage; (5) the presence of cuticular projections or pubescence on the antennomeres; (6) the long ligula (shared only with Paracymus rufocinctus) (in Orchymont's $(1913,1940)$ descriptions of larval Anacaena the length of the ligula is shorter than the labial palps); (7) the lobed proscutum (Figs 9, 11); (8) the shape of abdominal tergal plate VIII (Figs 10, 12). These similarities are not shared with larvae of Paracymus and Notionotus, suggesting a close relationship between the genera Anacaena and Crenitis. Of course, descriptions of larvae of the remaining genera are needed for a more complete view of the generic relationships within the tribe Anacaenini.

ACKNOWLEDGEMENTS. We want to thank A. Komarek (Naturhistorisches Museum, Wien) for confirming the identification of the adults associated with the described larva, to R.B. Angus (University of London) and to an anonymous reviewer for valuable comments and notes to the manuscript. The present study was partly supported by a grant from the Ministry of Education (MŠMT ČR) J13-98113100004.

\section{REFERENCES}

Archangelsky M. 1997: Studies on the Biology, Ecology, \& Systematics of the Immature Stages of New World Hydrophiloidea (Coleoptera: Staphyliniformia). Bull. Ohio Biol. Survey (N.S.) 12(1): 1-207 + i-ix.

ArCHANGElsky M. 1999: Immature stages of Paracymus rufocinctus Bruch, 1915 and Enochrus (Methydrus) vulgaris (Steinheil, 1869) (Coleoptera: Hydrophilidae: Hydrophilinae). Elytron 13: 87-99.

ArChangelsky M. 2004: Higher-level phylogeny of Hydrophilinae (Coleoptera: Hydrophilidae) based on larval, pupal, and adult characters. Syst. Entomol. 29(2): 188-214.

Bameul F. 2001: Description d'une nouvelle Anacaena Thomson de Corse (Coleoptera, Hydrophilidae). Bull. Soc. Entomol. Fr. 106: 225-232.

Berge Henegouwen A.L. van 1986: Revision of the European species of Anacaena Thomson (Coleoptera: Hydrophilidae). Entomol. Scand 17: 393-407.

Bøving A.G. \& HenriKsen K.L. 1938: The developmental stages of the Danish Hydrophilidae. Vidensk. Medd. Dansk. Naturh. Foren., Khobenhavn 102: 27-162.

EMDEN F. VAN 1932: Ergebnisse einiger Moorexkursionen im West-Erzgebirge. Koleopt. Rdsch. 18: 140-150.

Fernández L.A. \& Bachmann A.O. 1998: Hydrophiloidea. In: Morrone J.J. \& Coscarón S. (eds): Biodiversidad de Artrópodos Argentinos: Una Perspectiva Biotaxonómica. Ediciones Sur, La Plata, pp. 218-226.

Gentili E. 1992: The Notohydrus of Australia (Coleoptera: Hydrophilidae). Boll. Soc. Entomol. Ital. 124: 21-26.

GentiLi E. 1993: Paranacaena Blackburn, 1889: a valid genus (Coleoptera, Hydrophilidae). Giorn. Ital. Entomol. 6: 285-296.

Gentili E. 1996: Notes on the Anacaenini from Australia and Melanesia with descriptions of new species (Coleoptera, Hydrophilidae). Giorn. Ital. Entomol. 8: 177-189.

Gentili E. 2000: The Paracymus of Australia (Coleoptera, Hydrophilidae). Rec. South Austral. Mus. 33: 101-122.

Gentili E. 2002a: Descrizione di nuove specie del genere Paranacaena Blackburn, 1889 (Coleoptera, Hydrophilidae). Giorn. Ital. Entomol. 10: 77-97.

GentiLi E. 2002b: Hebauerina, new genus of water beetle from Thailand (Coleoptera, Hydrophilidae). Giorn. Ital. Entomol. 10: 141-145. 
Hansen M. 1991: The hydrophiloid beetles. Phylogeny, classification and a revision of the genera (Coleoptera, Hydrophiloidea). Biol. Skrifter 40: 1-367.

HANSEN M. 1999a: Fifteen new genera of Hydrophilidae (Coleoptera), with remarks on the generic classification of the family. Entomol. Scand. 30: 121-172.

Hansen M. 1999b: World Catalogue of Insects. 2. Hydrophiloidea (Coleoptera), Apollo Books, Steenstrup, 416 pp.

HANSEN M. 2000: On the identity of Anacaena tepida Winterbourn (Coleoptera, Hydrophilidae). N. Z. Entomol. 23: 85.

Hebauer F. 1994: The Crenitis of the Old World (Coleoptera, Hydrophilidae). Acta Coleopterol. 10: 3-40.

Hebauer F. 1999: Neue und wenig bekannte Hydrophiloidea aus dem südlichen Afrika (Coleoptera, Hydrophiloidea). Acta Coleopterol. 15: 7-16.

Hebauer F. 2001a: Beitrag zur Kenntnis der Hydrophilidae von Neuguinea. Ergebnisse der zoologischen Forschungsreisen von M. Balke und L. Hendrich nach West Neuguinea (Irian Jaya) in den Jahren 1990-1998. (Coleoptera: Hydrophilidae). Acta Coleopterol. 17(1): 3-72.

Hebauer F. 2001b: The genus Notionotus Spangler, 1972 in the Old World (Coleoptera: Hydrophilidae). Acta Coleopterol. 17(4): 9-14.

Ji L. \& KomareK A. 2003: Hydrophilidae: II. The Chinese species of Crenitis Bedel, with descriptions of two new species (Hydrophilidae). In Jäch M.A. \& Ji L. (eds): Water Beetles of China. Vol. III. Zoologisch-Botanische Gesellchaft in Österreich and Wiener Coleopterologenverein, Wien, pp. 397-409.
Matthey W. 1976: Description de la nymphe de Crenitis punctatostriata (Letzn) (Coleoptera, Hydrophilidae). Bull. Soc. Neuchatel. Sci. Nat. 100: 13-15.

Oliva A., Fernández L.A. \& Bachmann A.O. 2002: Sinopsis de los Hydrophiloidea acuáticos de la Argentina (Insecta, Coleoptera). Monografias Mus. Argent. Cienc. Natur. 2: 1-67.

ORCHYMONT A. D' 1913: Contribution à l'étude des larves hydrophilides. Annls. Biol. Lac. 6: 173-214 + i-xxiii.

Orchymont A. D' 1940: Les Palpicornia des îles Atlantiques. Mem. Mus. Roy. Hist. Nat. Belg. 20(2): 1-87.

ORCHYMONT A. D' 1942: Contribution à l'étude de la tribu Hydrobiini Bedel, spécialement de sa sous-tribu Hydrobiae (Palpicornia-Hydrophilidae). Mem. Mus. Roy. Hist. Nat. Belg. 24(2): 1-68

RichmOND E.A. 1920: Studies on the biology of aquatic Hydrophilidae. Bull. Am. Mus. Nat. Hist. 42: 1-94.

SHAARAwI F.A. 1989: Chromosomal Investigations on European Hydrophilidae (Coleoptera). Ph.D. Thesis, University of London, $176 \mathrm{pp}$.

ShaARawi F.A. \& Angus R.B. 1991: A chromosomal investigation of five European species of Anacaena Thomson (Coleoptera: Hydrophilidae). Entomol. Scand. 21[1990]: 415-426.

WINTERBOURN M.J. 1971: The larva of Anacaena tepida (Coleoptera: Hydrophilidae) from a Rotorua hot spring. N. Z . Entomol. 5: 171-174.

Received January 29, 2004; revised May 10, 2004; accepted August 16, 2004 